\title{
The History of the Democratic Adult Education Movement in Spain
}

\author{
ESTHER OLIVER University of Barcelona \\ ITXASO TELLADO University of Vic \\ MONTSERRAT YUSTE Autonomous University of Barcelona \\ ROSA LARENA FERNÁNDEZ University of Valladolid
}

Background/Context: Traditional adult education in Spain treated the learner as a mere object that could be shaped by the educator. Although current practices of the democratic adult education movement in Spain reveals a completely opposite standpoint on adult education, there has been little analysis of the several influences converging and complementing one another to form the historical antecedents for the creation of the democratic adult education movement that emerged in the turn of the century, in 2000, in Spain.

Purpose: This article aims to study the origins of the democratic adult education moviment in Spain by examining (1) the historical educational experiences in Spain, particularly before the dictatorship period and (2) the influences of some social and educational theories.

Research Design: Using historical analysis and literature analysis, this article is focused on the history of adult education in Spain, and, more particularly, presents an exhaustive document analysis based on historical aspects associated with the formation of the democràtic adult education movement.

Findings/Results: The findings suggest that the shaping of the democratic adult education movement in Spain has been influenced by three main strands: the Spanish libertarian moviment of the early 20th century, Paulo Freire's work and insights on adult education, and other social and educational theories from contemporary authors who conceive education as a tool for overcoming inequalities. In the present article, we show the influence of these strands on the DAE by identifying three main characteristics underpinning the movement, that is, the participants' self-organization and management based on egalitarian dialogue, the recognition of the universal capability of communication and knowledge creation, and the access to higher culture by the working-class people.

Conclusions/Recommendations: This article concludes that many of the educational practices developed under the democratic adult education movement are radically democratic, given that it promotes providing working-class people with access to higher culture while building up solidarity ties with the most disadvantaged. The present research shows how the DAE movement and all its components open up new lessons for successful inclusion practices in adult education and its effects on the promotion of social transformations at the local, national, and international levels. 